istand. This implies that a great deal of dry land must then have been under water. In 1834 Sir Charles Lyell wrote his Bakerian lecture, in which he brought forward overwhelming evidence to prove that Scandinavia was then being gradually upheaved. Celsius, who wrote in the I 7 th century, had affirmed it, and calculated the rise at forty inches in a century. In I8O7 Von Buch wrote that all the country from Frederickstadt, in Sweden, to Abo, in Finland, and perhaps as far as St. Petersburg, was slowly rising. Other authorities concurred, and lastly Sir Charles Lyell, who had approached the subject as a sceptic, was fully convinced after an exploration of the ground. At Stockholm he found striking proofs of change since the Baltic acquired its present tenants, Testacea found there seventy feet above the sea level being identical with those found in the adjacent sea. At Soderleige, a little farther south, and in a bed ninety feet above the sea level, besides the shells were found several buried yessels, made of wood, and joined with wooden pegs. In another place an iron anchor and nails were found. At Upsala brackish water plants were found in meadows where there are no salt springs; a proof that the sea had only recently retired. At Oregrund, forty miles to the north, the land had risen five inches and a half since 1820 , and at Gefle were low pastures, where the inhabitants' fathers remembered boats and even ships floating. Experienced pilots in the Gulf of Bothnia estimated the fall of the waters at two feet in thirty years. Since Sir Charles Lyell's lecture both the Russians and the Swedes have made experiments all proving the same fact.

To the east of Scandinavia we have Finland, exhibiting all the characteristics of a recently-emerged land. It is a mere congeries of lakes and swamps, separated by moss and sand. The level of the lakes is constantly falling. In 1818 Lake Sovando was suddenly lowered; its waters escaped into Lake Ladoga, and much of its bottom was exposed. Similar traditions about low meadows but recently crossed by boats and ships to those existing in Sweden prevail here also, and there seems good ground for believing that in the days of the Norsemen the White Sea and the Gulf of Finland were joined by a considerable strait. Farther east, again, we have the experience of Murchison and his companions, who found on the banks of the Dwina and Vaga recent shells still retaining their colour, and of the same species as those found in the Arctic Sea. In Spitzbergen, Mr. Lamont reports (see vol. xviii. of the "Quarterly Journal of the Geographical Society") that he discovered recent bones and drift wood several miles inland and high above high-water mark, skeletons of whales thirty to forty feet above the sea level. The seal fishers told him the land was rising, and that the seas thereabouts were now too shallow for the right whale, which had forsaken the Spitzbergen coast. This is confirmed by Malmgren (see Petermann's Mittheilungen, 2, 1863). Farther east we have the Tundras between the Karen Sea and the Gulf of the Obi presenting bare desolate flats that look as if they had only recently Middendorf describes the surface of the great emerged. Tundra as coated with fine sand like that now being deposited by the Polar Sea. Von Wrangel has many useful remarks to prove my position. He tells us that Diomed Island, mentioned by Laptev and Schalaurov, is now joined to the mainland; the coast of the Swatoi Ness, which they describe as very indented and ruinous, is now straight. The Bear Islands are mere heaps of ice and stones, evidently but recently covered with water; and shoals and banks now occupy what was tolerably deep water in 1787 when Captain Sarypchew was there.

Herdenstrom, in I810, found large birches scattered about the Tundra, $3^{\circ}$ to the north of any known Siberian forest; probably drift wood such as Wrangelhimself found drifting in the Polar Sea. Whales have now almost deserted the Siberian shores, where in the eighteenth century they were common. This is, no doubt, due to the shallowing of the water, as is the case in the Spitzbergen Sea. The shores of the Polar Sea, from the Lena to Behring's Straits, are for the most part low and flat. In winter it is hard to say where land ends and sea begins. A few versts inland, however, a line of high ground runs parallel with the present coast, and formerly, no doubt, constituted the boundary of the ocean. This belief is strengthened by the quantity of drift wood found in the Upper Level, and also by the shoals that run out, and will, no doubt, become dry land (Vide Wrangel's Introduction). "At several places along the coast we found old weathered drift wood at the height of two fathoms above the present level of the sea, whilst the lower drift wood lay at a level, indicating a change of level." Moving farther east again across Behring's Straits, we find Captain Beechey describing the across Behring s Straits, we narated from the sea by low flats with bones, \&c., on them. I carnot speak with the same confidence of the vast archipelago that bounds America on the north, nor about the northern shores of America, my researches having been confined to Asia, but evidence must abound in the Arctic voyages. Drift wood and bones of whales are mentioned on high ground by several of them. If it be permitted to quote the works of M. Reclus as an authority, and $I$ believe it to be a most sound book, he says, page 628 , numerous indications of the phenomenon (i.e. of the upheaval of the circumpolar. land of North America) have been recognised in the Arctic islands, scattered off the coasts of the Continent. At Port Kennedy Mr. Walker found shells of the present period at a height of 557 feet above the sea; a bone of a whale lay at a height of 164 feet. Again, page 65I, after saying that Solthern Greenland is being depressed, he continues, "On the north of Greenland, from lat. $76^{\circ}$, and in Grennell's land, \&c., the directly contrary phenomenon is taking place." Hayes discovered on all the coasts the existence of ancient sea-beaches which had gradually risen to the height of Ioo feet.

I have thus shown good ground for entertaining the notion that the land at present rising about the Pole is a continuous area, and is not rising merely in detached masses as M. Reclus's and Mr. Murray's maps (Geographical Distribution of Mammals) would lead us to suppose. I believe, further, that this area, bounded on the south by about the 57 th parallel of latitude, is the only area in the Northern Hemisphere which is at present undergoing upheaval. I should feel grateful to any of your correspondents who would point out where there is another area (of course excepting local disturbance immediately round a volcanoe); or would direct me to any authorities throwing light on the question I have advanced, which for anything I know may be an old theory, or even an exploded heresy.

Not only is the land around the Pole rising, but there is evidence to show that the nearer we get to the Pole the more rapid the rise is. This has been shown most clearly in the case of Scandinavia by Sir Charles Lyell, who most carefully guaged the rise at different latitudes from Scania, where the land is almost stationary, to the northern parts of Norway, where the rise is four feet in a century. While in Spitzbergen and the Polar Sea of Siberia, if in the memory of seal fishers and uthers the water has shallowed so fast as to have excluded the right whale, we may presume that the rate of emergence continues to increase, until it reaches its focus at the Pole, as it certainly diminishes until it disappears towards the south between the $5^{6}$ th and 58 th parallels of Jatitude. The subject is one of paramount importance to those who are trying to work out the history of the earth, and I once suggested at the British Association that it should be made the work of a special report, but $I$ was snubbed. I appeal with more confidence to you, sir, to help me to ventilate it. The question of the subsidence of other areas, and of the correlated climatic change, I will reserve for another letter.

Derby House, Eccles

\section{THE ENGLISH GOVERNMENT ECLIPSE}

\section{EXPEDITION}

$\mathrm{M}$

ANY of the readers of NATURE are no doubt interested in the fate of the Eclipse Expedition of I87 I. I will therefore give a sketch of their doings to the present time.

The P. and O. steamer Mirzapore, having the party on board, left Southampton on Oct. 26 , and, after a rather rough voyage, reached Malta on Nov. 4; left again the same evening, and arrived at Port Saïd on the 8th; entered the Canal at once, and anchored at Suez on the Ioth. Here she remained till the I2th, awaiting the arrival of the Brindisi mails; then left for Galle, where she arrived the 27 th. On leaving the Channel a strong: S.W. breeze was encountered, which soon increased to half a gale. The ship, though a roller, is a good sea boat, and made good progress; but the bad weather continued with little abatement until the Mirzapore was well in the Mediterranean, and nearing Malta. The sea then became calmer, the sun shone out, and the passengers, many of 
whom had not before emerged from their cabins, now came out as gay as possible, ready to make an impression at Malta. Our astronomers, who had not been exempt from the common fate of those who try the sea without a special education, now quickly roused themselves to make use of the opportunities for overhauling their instruments, and practising themselves for the work before them. The officers of the ship kindly gave every assistance, and those instruments that could be used on so unsteady a platform as a ship's deck were brought up from the hold, in which they had lain safely during the gale in the Bay, mounted on temporary stands, and used most diligently to investigate the changing phenomena with which we were surrounded. Classes also for mutual instruction were formed, so that each observer, on being detached in India, might - no matter what his special forte, whether spectroscope or polariscope-be able to impart instruction to the volunteers that we hope to obtain in India to aid in the good work. Our party numbered ten, viz. : Mr. Lockyer, chief, Messrs. Abbay, Moseley, Friswell, Capt. Tupman, R.M.A., and Commander Maclear, R.N., spectroscope observers; Dr. Thomson and Mr. Lewis, polarisers ; Mr. Holliday, artist ; and Mr. Davis, photographer. At Suez we were strengthened by the addition of Signor Respighi, from Rome, who has so distinguished himself by his observations of the solar atmosphere. The other passengers took great interest in the doings of the "Wise Men of the East," as they called us, and at their request, the day before arrival at Malta Mr. Lockyer gave a lecture on the advances that had been made of late years in solar physics, and on the object of this expedition.

Observations were made, as opportunities were given by clear sunrise and sunset at sea, on the alterations that take place in the abscrption bands as the sun rises from the horizon; and here may be mentioned the interesting result, that whilst in the open sea the bands at sunrise and sunset were, with slight variations, the same as observed by Lieut. Hennesey (paper read before the Royal Society May 21, 1870 ) whilst passing through the Suez Canal and down the Red Sea, the lines attributed to aqueous vapour near $C$ and $D$ were weaker, and although the colour of the hills about Suez was of a delicate purple, especially at sunset, the violet end of the spectrum could hardly be seen.

In the Indian Ocean, when the air was close and filled with moisture, and the N.E. monsoon blowing, the absorption bands near the horizon became very strong, and it was very interesting during the afternoon to fix a telescope with spectroscope attached, so that the horizon bisected the field; the spectrum of the air above the horizon then gave the absorption bands, but they were very faint in the light reflected on the water from the upper part of the sky, and they could be seen lengthening and shortening as the ship rolled towards or from that side. On pointing the spectroscope at the sky above, only the ordinary solar spectrum could be seen.

The Canal was entered on the 8 th of November about 3 P.M., and the ship anchored at Suez at noon on the loth. The Mirzapore is one of the largest veșsels that has passed through the Canal, and though she got through safely, it must not be supposed that she did not touch at all; in fact, the Canal is so narrow that too little room is left to allow for the time that so long a ship ( 400 feet) requires to answer her helm, especially at slow speed; and though the helm was shifted, and in some cases the engines reversed, as soon as the bow deviated from the straight line between the piles marking mid-channel, she could not be prevented touching several times. The narrowness also occasions delay when two vessels have to pass, one having to haul close in to the bank, and make herself as small as possible while the other goes by. But it is a grand work, and we have fully experienced the advantage of it, in avoiding the trans-shipment of our instruments, and the rough handling they would have experienced crossing the desert. We anchored in the Bitter Lakes on the evening of the gth. The cause of the name they bear was shown by the fact, attested by our engineer, that the water was much salter than in the canal on either side.

On arrival at Galle we were delighted to find that Admiral Cockburn had brought his flag-ship the Glasgors to meet us, and convey our Indian party to Beypoor and Baikul. He has kindly placed all his accommodation at our disposal whilst he visits Ceylon. All our instruments were embarked yesterday, and we leave this morning for Beypoor, where we hope to arrive on the 2 nd. The colonial steamer Serendib left yesterday with the parties for Jaffna and Trincomalee.

I can now give you the last dispositions of our party. In consequence of $M$. Janssen taking his station on the Neilgherries, we shall occupy two stations in Ceylon: Jaffna, where will be Captain Fyers, R.E., Captain Hogg, Captain Tupman, R.M.A., and Mr. Lewis ; and Trincomalee, Mr. Moseley and Mr. Ferguson.

In India, Baikul or Ootacamund will be our head quarters, occupied by Messrs. Lockyer, Davis, Maclear, and Dr. Thomson; at Manantawhaddy, Messrs. Abbay and Friswell; at Poodacottah, Mr. Holliday and M. Respighi.

I hope I shall be able to tell you of the success of our efforts.

Galle, Ceylon, Nov. 28

J. P. MACLEAR

The following provisional arrangements have been made in order to save time after arrival at Galle. Observers are warned that they are liable to alteration on receipt of information from the Indian and Ceylon authorities :-

$\mathrm{x}$. The expedition will be divided into six parties as follows : (I) Lockyer, Thomson, Maclear; (2) Respighi, Holliday; (3) Tupman, Lewis, Ferguson; (4) Abbay, Friswell ; (5) Moseley; (6) Davis.

2. Each party will be under the charge of the observer just named in each party, who will be held responsible for the instruments, \&c., detailed for the use of observers. He will also be the channel of communication with the local authorities, and will make arrangements for the observations to be made by local volunteers.

3. Special instructions will subsequently be issued for the observations, and stations will be named. Each observer will be responsible to the chief of the expedition alone for these observations.

4. The observers in charge of each party will hand in to the treasurer a receipt for the instruments, \&c, detailed for each party.

5. The observer in charge of each party will make a list of the cases containing the instruments, \&c., ard will arrange for their transfer from the Mirzapore, and for their future transit.

6. He will be held responsible for the repacking of the irstruments after the eclipse, and for their transmission to Galle or Bombay.

To this we are able to append the following official instructions :-

The Ceylon party to be as follows:--Captains Fyers, Hogg, and Tupman; Messrs. Moseley, Lewis, Ferguson, jun., and Fœnandez.

Observing Stations to be as follows:-I. Jaffna and station south ; 2. A position as far north of Trincomalee as possible, and a station south.

Instruments to be detailed as follows:- recording Dublin spectroscope, Capt. Fyers; tube Dublin spectroscope, Mr. Ferguson; analysing spectroscope, Mr. Moseley ; camera, Capt. Hogg ; polariscope, Mr. Lewis.

Mr. Fœnandez should observe on the central line. $\mathrm{He}$ should instruct two observers to make drawings of the Corona on a plan similar to his own near the southern limit of totality.

The recording spectroscope to be used to determine coronal lines in the red end of the spectrum to, and in- 
cluding, $F$. A high power should be used, and the prisin should be adjusted for the minimum deviation of the central ray of this portion.

The tube spectroscope should be used in a similar manner for the other part, including $F$. Intensities referred to $F$ to be most carefully noted.

Care to be taken that observers are not interrupted for two hours after totality.

Instruments to be returned to Galle, and shipped in $P$. and $O$. steamer, consigned to J. Browning, I I , Minories, London, E.C. All observations, photographic plates, drawings, \&c., to be sent to Mr. Lockyer within a week of the eclipse. Observers to keep exact duplicates in case of loss.

The following resolutions were passed by the Government of India in the Home Department-under date 27th July and 2ist October :-

"Colonel Tennant has already been authorised demiofficially to provide the astronomical instruments and photographic apparatus that he will require for his observations, and the Governor-General in Council understands that he is now in communication with Prof. Airy and Mr. Huggins on the subject. The cost of these appliances has been included in the estimate appended to Colonel Tennant's memorandum.

"In addition to these instruments, Colonel Tennant will require the aid of qualified observers, and it has been ascertained that the Superintendent of the Great Trigonometrical Survey is prepared to place the services of $\mathrm{Mr}$. Hennessey and Captain Herschel, belonging to his department, temporarily at the disposal of Colonel Tennant for this purpose without prejudice to their proper duties. The Governor-General in Council approves of this arrangement, and is pleased to direct that the Survey officers above-named shall suffer no loss of their allowances while so employed, and that they shall have their travelling expenses paid out of the allotment of Rs. 15,000 sanctioned on account of the Eclipse observations. Colonel Tennant will arrange with Major Montgomerie beforehand when the officers in question should join them.

"The Governor-General in Council is further pleased to direct that Colonel Tennant shall receive from the Surveyor General's Department all the aid that he may require as regards photographic assistants, chemicals, \&c.

"Lastly, the Governor General in Council is pleased to direct that the report of the result of Colonel Tennant's observations, and his accounts, shall be submitted by him to this department."

"From the correspondence received with the above despatch, the Governor General in Council has learnt that an expedition is being sent out from England under instructions from the Eclipse Committee of the British Association, and he is desirous that the Government of Madras will afford the expedition such assistance as it may require in the furtherance of its operations. Such assistance will probably consist in the provision, on a moderate scale, for three or four persons, at each place selected, of tents, means of subsistence, and locomotion, and in the erection of temporary observatories of a simple form. It may also be desirable to depute one or two persons to each party from the Public Works Department to assist the observers.

"Information has also been received that the French Government has deputed M. Janssen to visit India with the same object, and the Governor General in Council desires that the Government of Madras will afford every facility and assistance to that gentleman also.

"The Financial Department will be moved to sanction any reasonable expenditure that may be necessary to enable the Government of Madras to give effect to these instructions,"

\section{ARCTIC EXPLORATIONS}

A SHORT paper of mine on the above subject appeared in NATURE of the 7 th December, in which I stated some reasons for my belief that Smith Sound possesses no apparent advantages over Spitzbergen as a route by which to reach a very high northern latitude or the Pole itself. In fact I think the advantages are all the other way; and I shall endeavour to show one or two more reasons than I have already given for this belief.

Kane's and Hayes' ships were stopped by ice in Smith Sound before they reached lat. $79^{\circ}$, and this, I think, can readily be accounted for by the peculiar contour of the coast-line, as may be seen by the accompanying rough outline, taken from a copy of Dr. Hayes' chart in the Royal Geographical Society's Map-room.

The width of Kennedy Channel (a continuation of Smith Sound) is at $80^{\circ}$ north lat. about 40 miles, but between latitudes $79^{\circ}$ and $80^{\circ}$, Smith Sound expands to a width of something like 100 miles, this expansion being chiefly formed by a large bay on the east side. The south point of this bay, which I have marked $A$ in the accompanying chart, runs far to the west in lat. $78^{\circ} 30^{\prime}$ (thus changing the direction of the Sound from nearly true north and south to N.E. and S.W.), and approaching within 30 miles of the west shore at the point $B$.

If there is, as I believe, a set or drift of current southward, the ice will first be pressed with great force-as Kane found to his cost-against that side of the bay of which $A$ is the south point, and then it will be driven across to the west shore somewhere near $B$ at the narrowest part of the Sound in a closely-packed and continuous stream of heavy floes hitherto found impene. trable.

Should this idea be correct, and there is something more than theory to support it, this obstruction will be a constant and not an occasional one as long as there is a supply of ice to the north.

If there is a large opening extending far to the west at the place marked $C$, we have another probable opposing element; for if the set of current runs eastward through it, we shall have an important addition to the Smith Sound supply of ice, in making the barrier of the "pack" more formidable. The opinion I express as to the direction of the currents is not wholly hypothetical, for we have proofs of an almost constant current (it is sometimes reversed by strong winds) setting southward down Baffin's Bay and Davis Strait ; and this current can only be fed by Lancaster and Smith Sounds and other openings to the west and north.

The only hope of an "easy" passage up Smith Sound to a higher latitude than $78^{\circ} 40^{\prime}$ is the existence of Kane's "great open Polar Sea," for if such sea does exist, there would be no ice to the northward to keep up the supply of this commodity in Smith Sound, which would in the summer months be cleared of its winter covering by the southerly drift I have already mentioned, and the Sound would, and probably will be, consequently free from ice in August. But this is opposed to both Kane's and Hayes' experience, whatever their expressed opinions about the large open sea may have been.

That Kane's man Morton saw a very considerable extent of open water is not to be doubted, also that it may be quite true that he saw no ice to the northward, although he put down a point of land (whether correctly or not it is difficult to say) seventy miles distant in that direction. Every one, however, must be aware-for it is not necessary to have been in the Arctic seas to acquire such knowledge--that when the temperature of the air is lower than that of the water, a vapour or haze is formed by condensation, which, although by no means dense when looking through a small extent of it, becomes so much so when the observer has to look through eight or ten miles of it, that any low object, such as floe ice, would be quite in-s 